\title{
Effect of Inhaled Corticosteroid Withdrawal on Chronic Obstructive Pulmonary Disease Exacerbations in Patients Taking Triple Therapy at Baseline
}

Gary T Ferguson'

Asif Shaikh (D) ${ }^{2}$

Kay Tetzlaff ${ }^{3}$

Achim Mueller $\mathbb{D D}^{3}$

Helgo Magnussen ${ }^{4}$

Henrik Watz ${ }^{4}$

'Pulmonary Research Institute of Southeast Michigan, Farmington Hills, MI, USA;

${ }^{2}$ Boehringer Ingelheim Pharmaceuticals, Inc, Ridgefield, CT, USA; ${ }^{3}$ Boehringer Ingelheim Pharma GmbH \& Co. KG, Biberach an der Riss, Germany; ${ }^{4}$ Pulmonary Research Institute at Lung Clinic Grosshansdorf, Airway Research Center North (ARCN), German Center for Lung Research (DZL), Grosshansdorf, Germany

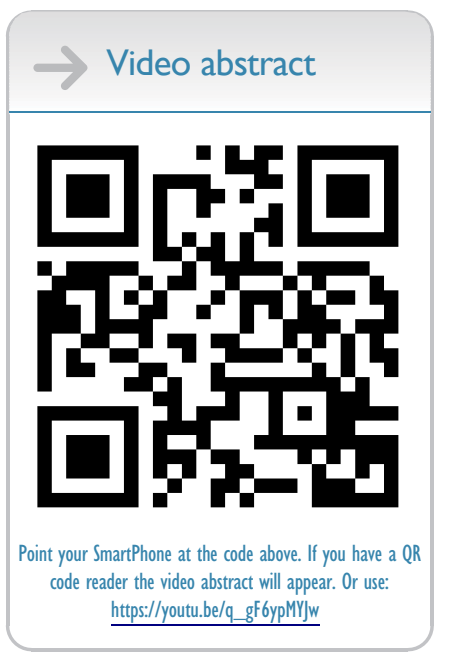

Correspondence: Gary T Ferguson Pulmonary Research Institute of Southeast Michigan, Suite A, 29255 W 10 Mile Road, Farmington Hills, MI, USA

Tel + | 248-478-656 |

Fax +| 248-478-6908

Email garytferguson@msn.com
This article was published in the following Dove Press journal:

International Journal of Chronic Obstructive Pulmonary Disease

Purpose: In the Withdrawal of Inhaled Steroids during Optimized Bronchodilator Management (WISDOM) trial, inhaled corticosteroid (ICS) withdrawal in patients with chronic obstructive pulmonary disease receiving triple therapy (long-acting $\beta_{2}$-agonist+long-acting muscarinic antagonist $+\mathrm{ICS}$ ) did not change moderate/severe exacerbation risk. However, many patients were not taking triple therapy before study participation. This analysis was conducted to eliminate the impact of non-ICS users on WISDOM results by re-analyzing the data using only the subset of patients who were taking triple therapy at screening.

Patients and Methods: The effect of ICS withdrawal on moderate/severe exacerbation risk in the subgroup of WISDOM patients taking triple therapy before enrolling in the study was evaluated in this post hoc analysis. Additionally, the effect of ICS withdrawal in patients with a history of $\geq 2$ exacerbations in the previous year and various blood eosinophil counts was assessed.

Results: Overall, 39.0\% ( $\mathrm{n}=970$ : ICS continuation, 479; ICS withdrawal, 491) of the WISDOM trial population were taking triple therapy at screening. Baseline characteristics were generally similar between groups. Moderate/severe exacerbation risk between the ICS withdrawal and continuation groups (hazard ratio [HR], 1.05; 95\% confidence interval [CI]: 0.89-1.25) was not increased in patients taking triple therapy at screening versus the overall trial population (HR [95\% CI]: 1.06 [0.94-1.19]). However, in patients with a history of $\geq 2$ exacerbations, exacerbation risk (HR [95\% CI]) increased nominally with blood eosinophil count from $1.07[0.81-1.41](\geq 100$ cells $/ \mu \mathrm{L})$ to $1.45[0.58-3.60](\geq 400$ cells $/ \mu \mathrm{L})$.

Conclusion: Consistent with results from the overall WISDOM trial population, ICS withdrawal did not increase exacerbation risk in patients taking triple therapy at screening. Patients with a history of frequent exacerbations and higher blood eosinophil counts could benefit from continuation of ICS-based therapy.

Keywords: COPD, dual bronchodilator, glucocorticoid, triple therapy

\section{Introduction}

A maintenance bronchodilator (long-acting $\beta_{2}$-agonist [LABA] or long-acting muscarinic antagonist [LAMA]) has long been recommended in the Global Initiative for Chronic Obstructive Lung Disease (GOLD) strategy report for patients with chronic obstructive pulmonary disease (COPD) and breathlessness or exercise limitation. ${ }^{1}$ For patients with continued symptoms or an increased risk of COPD exacerbations, escalation to a LAMA+LABA combination is recommended. ${ }^{1}$ De-escalation of

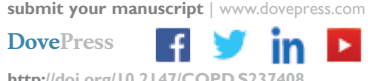

International Journal of Chronic Obstructive Pulmonary Disease 2020:I5 2879-2888

2879

cC) (i) 2020 Ferguson et al. This work is published and licensed by Dove Medical Press Limited. The full terms of this license are available at https://www.dovepress.com/terms. (c) php and incorporate the Creative Commons Attribution - Non Commercial (unported, v3.0) License (http://(creativecommons.org/licenses/by-nc/3.0/). By accessing the work you hereby accept the Terms. Non-commercial uses of the work are permitted without any further permission from Dove Medical Press Limited, provided the work is properly attributed. For permission for commercial use of this work, please see paragraphs 4.2 and 5 of our Terms (https://www.dovepress.com/terms.php). 
therapy for COPD is also proposed. ${ }^{1}$ Criteria for bronchodilator de-escalation include lack of symptomatic or functional response after adding a second bronchodilator or the development of significant adverse events associated with the added medication.

Collectively, the role of inhaled corticosteroids (ICS) in the treatment of COPD was further revised in GOLD 2020, and ICS are now recommended for use only in certain circumstances, namely in patients with a history of hospitalizations for COPD exacerbations or with $\geq 2$ moderate COPD exacerbations per year after failure with single or dual maintenance bronchodilator therapy or in patients with eosinophilia or a history of asthma. ${ }^{1}$

Unlike asthma, where ICS are a cornerstone of treatment, ${ }^{2}$ ICS may not be as broadly beneficial in patients with COPD due to the involvement of non-eosinophilic inflammatory cells, which may not respond effectively to ICS treatment. ${ }^{3,4}$ Moreover, long-term use of ICS in patients with COPD can be associated with the risk of adverse events. ${ }^{4,5}$

Despite GOLD recommendations, real-world evidence shows inappropriate prescribing and overuse of ICS-containing therapy in COPD patients, for whom ICS are not clinically indicated. ${ }^{6-8}$ De-escalation or withdrawal of ICS therapy in COPD is now recommended if the original indication for starting an ICS was inappropriate or if an adverse outcome such as pneumonia occurs after adding an ICS or there is no clinical response to the added ICS. ${ }^{1}$ An eosinophil count of $<100$ cells $/ \mu \mathrm{L}$ has also been suggested as a potential indication for de-escalating from an ICS. ${ }^{1}$

Results of the Withdrawal of Inhaled Steroids during Optimized Bronchodilator Management (WISDOM) trial showed that stepwise withdrawal of ICS in patients with severe-to-very severe COPD and a history of or risk for COPD exacerbations after being placed on triple therapy for $\geq 6$ weeks was noninferior to ICS continuation for the risk of moderate or severe exacerbations. ${ }^{9}$ Some patients were receiving triple therapy at screening, but many were not. The reasons for medication choice for entry into the study were not determined. The SUNSET trial, ${ }^{10}$ a trial requiring clinical prescription and use of triple therapy for $\geq 6$ months prior to study entry, supports many of the findings of WISDOM. However, ICS withdrawal in a subset of patients on triple therapy with increased blood eosinophils resulted in an increased risk for exacerbations and deterioration of lung function. ${ }^{10}$

Prior analyses of WISDOM did not include the impact of ICS withdrawal on patients on triple therapy prior to the study. Consequently, the effect of ICS withdrawal in patients already taking triple therapy at screening was unknown. Identifying patients with COPD who are suitable for triple therapy and understanding whether or not and in which patients to de-escalate treatment from triple therapy to dual bronchodilator therapy is important. The objective of this post hoc analysis of data from the WISDOM trial was to evaluate the effect of ICS withdrawal on the risk of moderate or severe exacerbations in the subgroup of patients who were receiving triple therapy prior to study participation. Additionally, we assessed the effect of ICS withdrawal in those patients who had a history of $\geq 2$ exacerbations in the year before the study and blood eosinophil counts above different thresholds.

\section{Patients and Methods Study Design}

The design of the WISDOM trial (ClinicalTrials.gov number, NCT00975195) has been described previously., ${ }^{9,11}$ Briefly, WISDOM was a 12-month, multinational, randomized, double-blind, parallel-group, active-controlled trial. Patients were selected on the basis of their heightened risk for COPD exacerbations based on severity of lung function and history of $\geq 1$ documented exacerbation during the 12-month period before the initial screening visit. One week after screening, all patients entered a 6-week run-in period during which they received triple therapy with tiotropium (18 $\mu \mathrm{g}$ once daily) via HandiHaler ${ }^{\circledR}$ (a dry powder inhaler) and salmeterol (50 $\mu \mathrm{g}$ twice daily; 2 actuations of $25 \mu \mathrm{g})$ and fluticasone propionate $(500 \mu \mathrm{g}$ twice daily; 2 actuations of $250 \mu \mathrm{g}$ ) via a metered-dose inhaler. Patients were then randomized in a $1: 1$ ratio to either continue the same triple therapy as received in the run-in period (ICS continuation group) or continue tiotropium and salmeterol with a stepwise reduction of fluticasone for 12 weeks followed by stable therapy for 40 weeks (ICS withdrawal group) during the 52-week study period (Figure 1). ${ }^{9,11}$

The study was carried out in accordance with the Declaration of Helsinki, local regulations, and the International Conference on Harmonisation Harmonised Tripartite Guidelines for Good Clinical Practice. Local institutional review boards, independent ethics committees, and competent authorities approved the protocol (Supplementary Table 1). All patients provided written, informed consent. 


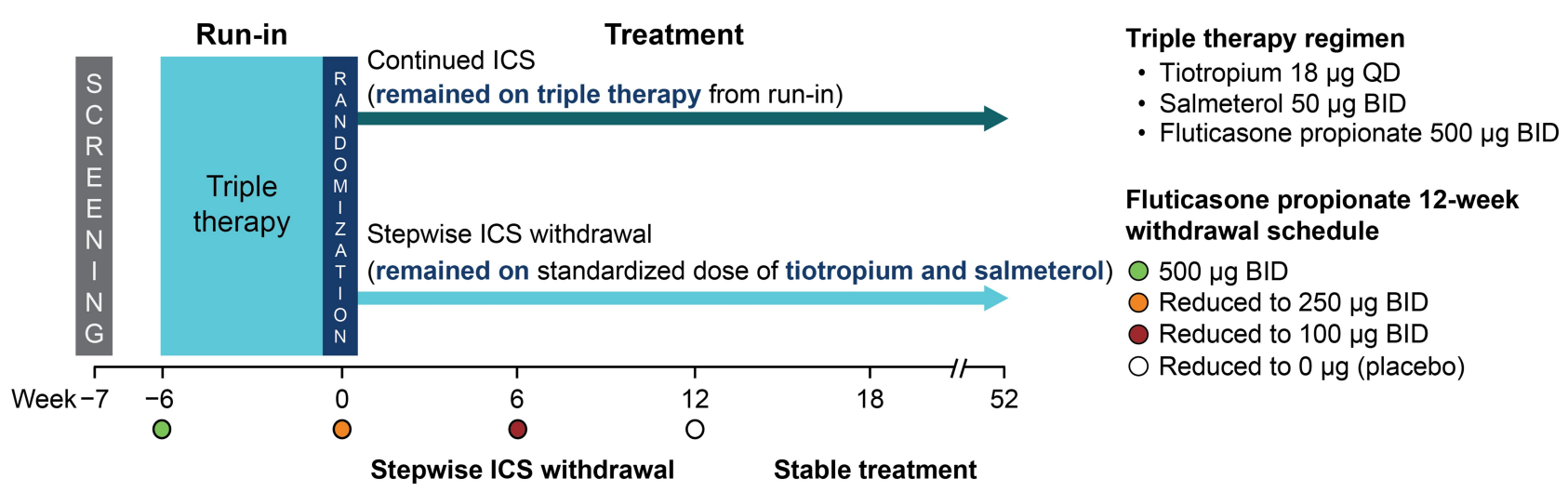

Figure I WISDOM trial design.

Abbreviations: BID, twice daily; ICS, inhaled corticosteroids; QD, once daily.

\section{Patients}

Patients who were aged $\geq 40$ years, were diagnosed with severe or very severe COPD (defined by forced expiratory volume in 1 second $\left[\mathrm{FEV}_{1}\right]<50 \%$ of the predicted volume and $\mathrm{FEV}_{1}<70 \%$ of forced vital capacity after bronchodilation), had a history of $\geq 1$ documented exacerbation in the 12 months before screening, and were either former or current ( $\geq 10$ pack-years) smokers were included. Patients with a clinical diagnosis of asthma were excluded. The full inclusion and exclusion criteria have been reported previously. ${ }^{11}$

In these subgroup analyses, patients taking triple therapy (LABA, LAMA, and ICS; with or without other pulmonary medication such as oral $\beta$-agonists, oral glucocorticoids, leukotriene receptor antagonists, mucolytic agents, oxygen, and xanthines) since the time of screening and irrespective of baseline blood eosinophil counts were included. Use of xanthines and mucolytic agents, but not maintenance oral glucocorticoid treatment, was allowed throughout the trial. All patients were provided with open-label salbutamol (albuterol) for use as needed. At the investigator's discretion, randomized treatment could be discontinued, and open-label fluticasone could be initiated for the remainder of the trial. ${ }^{9,11}$

\section{Endpoints and Assessments}

The primary endpoint was time to the first moderate or severe, on-treatment COPD exacerbation during the 52week randomized treatment period. Moderate or severe COPD exacerbation was defined as worsening or onset of $\geq 2$ lower respiratory symptoms related to COPD, such as shortness of breath, cough, wheezing, chest tightness, and sputum production and purulence, with $\geq 1$ symptom lasting for $\geq 3$ days and requiring a change in treatment. Moderate exacerbations were treated with antibiotics and/ or systemic steroids, whereas severe exacerbations required hospitalization or treatment in an urgent care unit. Exacerbations reported after discontinuation of randomized treatment were excluded in the primary endpoint analyses. The primary endpoint was additionally analyzed for the following subgroups: geographical region, age group, sex, smoking status, baseline values of body mass index (BMI), and 6-minute walk test. Secondary endpoints included the number of moderate or severe, on-treatment COPD exacerbations per year during the study period, and were additionally analyzed for subgroups with a history of $\geq 2$ exacerbations and blood eosinophil counts above various thresholds $(\geq 100$ cells $/ \mu \mathrm{L}$ to $\geq 400$ cells $/ \mu \mathrm{L})$.

\section{Statistical Analyses}

Time to first exacerbation was analyzed using a Cox proportional hazards model with adjustment for baseline $\mathrm{FEV}_{1}$. Annualized rates of exacerbations were obtained from a negative binomial regression adjusted for time at risk and compared by rate ratio (RR; ICS withdrawal versus continuation). This subgroup analysis was not formally powered.

\section{Results}

\section{Study Population and Baseline Characteristics}

Of the 2485 patients in the overall trial population who received tiotropium (18 $\mu \mathrm{g}$ once daily) and salmeterol+fluticasone propionate $(50+500 \mu \mathrm{g}$ twice daily) during the 6- 
week run-in period, $970(39.0 \%)$ were taking triple therapy at screening before the run-in period. These patients were roughly equally randomized to the ICS continuation $(n=479)$ and ICS withdrawal $(n=491)$ groups.

Baseline characteristics were generally similar between patients taking triple therapy at screening and the overall trial population (Table 1); most of the patients in both groups were male $(79.1 \%$ and $82.5 \%$, respectively), with a mean \pm standard deviation (SD) age of $64.3 \pm 8.1$ and 63.8 \pm 8.5 years, mean $\pm \mathrm{SD}$ postbronchodilator $\mathrm{FEV}_{1} \%$ predicted of $33.0 \pm 9.0$ and $32.8 \pm 9.1$, and mean $\pm \mathrm{SD}$ duration of COPD of $8.4 \pm 6.5$ years and $7.9 \pm 6.2$ years, respectively; in addition, most patients had GOLD grade $3(63.0 \%$ and $61.2 \%$, respectively) or 4 (36.3\% and $38.1 \%$, respectively) severity. Further, history of moderate-to-severe (mean $\pm \mathrm{SD}$, $1.8 \pm 1.3$ and $1.7 \pm 1.3$, respectively) and severe $(0.4 \pm 0.8$ and $0.4 \pm 0.8$, respectively) exacerbations in the previous year was comparable. Finally, fewer patients taking triple therapy at screening than those in the overall trial population had a baseline blood eosinophil count of $\geq 300$ cells $/ \mu \mathrm{L}$ (15.9\% versus $19.7 \%$, respectively).

\section{COPD Exacerbations}

The risk of moderate or severe COPD exacerbations was higher in the triple therapy group than in the overall population (Table 2), but the risk introduced by ICS withdrawal was not increased in patients receiving triple therapy at screening (hazard ratio [HR], 1.05; 95\% confidence interval [CI]: 0.89, 1.25; Table 2, Figure 2A) compared with that in the overall trial population (HR $[95 \% \mathrm{CI}]$ : 1.06 [0.94, 1.19]; Table 2, Figure 2B). Although the annual exacerbation rate was higher among patients taking triple therapy at screening than in the overall trial population, the RR for exacerbations was not increased following ICS withdrawal (RR [95\% CI]: 1.02 [0.86, 1.20] versus 1.05 [0.93, 1.18], respectively; Table 2). The risk of severe, on-treatment COPD exacerbations was increased in the subgroup of patients taking triple therapy at screening. However, the HRs and RRs for ICS withdrawal versus ICS continuation were similar for patients taking triple therapy at screening versus the overall trial population (HR [95\% CI]: 1.23 [0.92, 1.64] versus 1.20 [0.98, 1.48]; RR [95\% CI]: 1.12 [0.82, 1.53] versus 1.15 [0.92, 1.45], respectively) (Table 2, Figure $3 \mathrm{~A}$ and $\mathrm{B}$ ). Further, no obvious increase in the frequency of exacerbations following ICS withdrawal was observed within different time periods in the triple therapy group and the overall population (Supplementary Figure 1).
Across the different subgroups (geographical region, age group, sex, smoking status, baseline BMI, and baseline 6-minute walk test), HRs for time to first moderate or severe exacerbations were similar in the subgroup of patients taking triple therapy at screening (Figure 4A) and in the overall trial population (Figure 4B), suggesting the robustness of the results.

In patients taking triple therapy at screening with a history of $\geq 2$ exacerbations, exacerbation risk (HR [95\% $\mathrm{CI}]$ ) increased nominally (Figure 5) with blood eosinophil count from $1.07[0.81-1.41](\geq 100$ cells $/ \mu \mathrm{L})$ to $1.45[0.58-$ 3.60] ( $\geq 400$ cells $/ \mu \mathrm{L})$.

\section{Discussion}

Results from these post hoc analyses of the WISDOM trial data show that patients taking triple therapy - a LAMA, a LABA, and an ICS - at screening and during the run-in period had a higher risk of moderate or severe COPD exacerbations than those in the overall trial population. This suggests that history of exacerbations may have partly influenced clinicians to prescribe triple therapy in these patients to a greater degree. Importantly, the risk of COPD exacerbations associated with stepwise ICS withdrawal over a 12 -week period was not increased in this subgroup of patients receiving triple therapy at screening. These results are consistent with the main findings from the WISDOM trial, which showed that the risk of moderate or severe exacerbations was similar in patients receiving triple therapy who underwent ICS withdrawal and those who continued triple therapy. ${ }^{9}$

The main findings from the WISDOM trial ${ }^{9}$ and these post hoc analyses are consistent with those from other ICS withdrawal studies. In the SUNSET trial, where subjects on triple therapy without clear indication for ICS therapy ( $\leq 1$ moderate or severe exacerbation in the prior year) were abruptly discontinued from ICS by switching from open triple therapy to a LAMA+LABA combination, there was only a small decrease in lung function and no impact on COPD exacerbations in the overall treatment groups. ${ }^{10}$ Similarly, a subgroup analysis of the real-life, Outpatient Care With Long-Acting Bronchodilators: COPD Registry in Germany (DACCORD) study revealed that ICS withdrawal during a 2-year follow-up period did not increase the risk of exacerbations in patients with COPD who continued treatment with a LAMA or a LABA. ${ }^{12}$

On the other hand, conflicting results on the impact of ICS withdrawal have also been reported in some studies. In the single-center, COPD Study of the Department of 
Table I Disease and Patient Characteristics at Screening (Patients Taking Triple Therapy at Screening and the Overall Trial Population)

\begin{tabular}{|c|c|c|c|c|c|c|}
\hline & \multicolumn{3}{|c|}{ Triple Therapy at Screening } & \multicolumn{3}{|c|}{ Overall Trial Population } \\
\hline & $\begin{array}{l}\text { ICS } \\
\text { Continuation, } \\
n=479\end{array}$ & $\begin{array}{l}\text { ICS } \\
\text { Withdrawal, } \\
n=49 \text { I }\end{array}$ & Total, $n=970$ & $\begin{array}{l}\text { ICS } \\
\text { Continuation, } \\
n=\mid 243\end{array}$ & $\begin{array}{l}\text { ICS } \\
\text { Withdrawal, } \\
n=1242\end{array}$ & Total, $n=2485$ \\
\hline Age, years, mean $\pm S D$ & $64.5 \pm 8.0$ & $64.1 \pm 8.2$ & $64.3 \pm 8.1$ & $63.6 \pm 8.6$ & $64.0 \pm 8.4$ & $63.8 \pm 8.5$ \\
\hline \multicolumn{7}{|l|}{ Age groups, n (\%) } \\
\hline $\begin{array}{l}<55 \text { years } \\
\geq 55 \text { to }<65 \text { years } \\
\geq 65 \text { to }<75 \text { years } \\
\geq 75 \text { years } \\
\text { Male, } \mathrm{n}(\%) \\
\text { Body mass index, } \mathrm{kg} / \mathrm{m}^{2} \text {, mean } \pm \mathrm{SD}\end{array}$ & $\begin{array}{l}55(11.5) \\
185(38.6) \\
179(37.4) \\
60(12.5) \\
376(78.5) \\
25.7 \pm 5.0\end{array}$ & $\begin{array}{l}62(12.6) \\
192(39.1) \\
186(37.9) \\
51(10.4) \\
391(79.6) \\
25.6 \pm 5.1\end{array}$ & $\begin{array}{l}117(12.1) \\
377(38.9) \\
365(37.6) \\
111(11.4) \\
767(79.1) \\
25.7 \pm 5.0\end{array}$ & $\begin{array}{l}194(15.6) \\
473(38.1) \\
437(35.2) \\
139(11.2) \\
1013(81.5) \\
25.3 \pm 5.1\end{array}$ & $\begin{array}{l}164(13.2) \\
490(39.5) \\
455(36.6) \\
133(10.7) \\
1036(83.4) \\
25.2 \pm 5.1\end{array}$ & $\begin{array}{l}358(14.4) \\
963(38.8) \\
892(35.9) \\
272(10.9) \\
2049(82.5) \\
25.2 \pm 5.1\end{array}$ \\
\hline \multicolumn{7}{|l|}{ Body mass index groups, $n(\%)$} \\
\hline 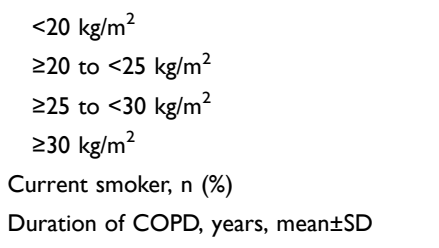 & $\begin{array}{l}59(12.3) \\
162(33.8) \\
175(36.5) \\
83(17.3) \\
145(30.3) \\
8.3 \pm 6.4\end{array}$ & $\begin{array}{l}61(12.4) \\
172(35.0) \\
175(35.6) \\
83(16.9) \\
141(28.7) \\
8.5 \pm 6.6\end{array}$ & $\begin{array}{l}120(12.4) \\
334(34.4) \\
350(36.1) \\
166(17.1) \\
286(29.5) \\
8.4 \pm 6.5\end{array}$ & $\begin{array}{l}186(15.0) \\
453(36.4) \\
401(32.3) \\
203(16.3) \\
432(34.8) \\
7.8 \pm 6.0\end{array}$ & $\begin{array}{l}183(14.7) \\
470(37.8) \\
388(31.2) \\
201(16.2) \\
399(32.1) \\
8.0 \pm 6.5\end{array}$ & $\begin{array}{l}369(14.8) \\
923(37.1) \\
789(31.8) \\
404(16.3) \\
831(33.4) \\
7.9 \pm 6.2\end{array}$ \\
\hline \multicolumn{7}{|l|}{ 6-minute walk test } \\
\hline $\begin{array}{l}\text { Patients with available data, } \mathrm{n} \\
\text { 6-minute walk test, } \mathrm{m} \text {, mean } \pm \mathrm{SD}\end{array}$ & $\begin{array}{l}472 \\
351.4 \pm \mid 14.7\end{array}$ & $\begin{array}{l}486 \\
343.3 \pm 128.4\end{array}$ & $\begin{array}{l}958 \\
347.3 \pm 121.8\end{array}$ & $\begin{array}{l}1234 \\
358.0 \pm 116.9\end{array}$ & $\begin{array}{l}1233 \\
353.5 \pm 123.3\end{array}$ & $\begin{array}{l}2467 \\
355.7 \pm 120.2\end{array}$ \\
\hline \multicolumn{7}{|l|}{ 6-minute walk test groups, n (\%) } \\
\hline $\begin{array}{l}<350 \mathrm{~m} \\
\geq 350 \mathrm{~m} \\
\text { Missing }\end{array}$ & $\begin{array}{l}23 \mid(48.2) \\
24 \mid(50.3) \\
7(1.5)\end{array}$ & $\begin{array}{l}228(46.4) \\
258(52.5) \\
5(1.0)\end{array}$ & $\begin{array}{l}459(47.3) \\
499(51.4) \\
12(1.2)\end{array}$ & $\begin{array}{l}574(46.2) \\
660(53.1) \\
9(0.7)\end{array}$ & $\begin{array}{l}562(45.2) \\
671(54.0) \\
9(0.7)\end{array}$ & $\begin{array}{l}\text { II } 36(45.7) \\
1331(53.6) \\
18(0.7)\end{array}$ \\
\hline \multicolumn{7}{|l|}{ Baseline lung function } \\
\hline $\begin{array}{l}\text { Patients with available data, n } \\
\text { Postbronchodilator } \mathrm{FEV}, \% \text { predicted, } \\
\% \text {, mean } \pm \mathrm{SD} \\
\text { Postbronchodilator FVC, L, mean } \pm \mathrm{SD} \\
\text { Postbronchodilator } \mathrm{FEV} / \mathrm{FVC}, \% \text {, mean } \\
\pm \mathrm{SD} \\
\text { Diagnosed with chronic bronchitis, n (\%) } \\
\text { Diagnosed with emphysema, n (\%) }\end{array}$ & $\begin{array}{l}479 \\
33.0 \pm 8.7 \\
2.5 \pm 0.8 \\
41.4 \pm 12.4 \\
318(66.4) \\
274(57.2)\end{array}$ & $\begin{array}{l}489 \\
33.0 \pm 9.4 \\
2.5 \pm 0.7 \\
41.6 \pm 11.7 \\
320(65.2) \\
280(57.0)\end{array}$ & $\begin{array}{l}968 \\
33.0 \pm 9.0 \\
2.5 \pm 0.7 \\
41.5 \pm 12.1 \\
638(65.8) \\
554(57.1)\end{array}$ & $\begin{array}{l}1240 \\
32.7 \pm 8.9 \\
2.4 \pm 0.7 \\
42.4 \pm 11.9 \\
772(62.1) \\
723(58.2)\end{array}$ & $\begin{array}{l}1240 \\
32.8 \pm 9.2 \\
2.4 \pm 0.7 \\
42.0 \pm 11.4 \\
810(65.2) \\
757(61.0)\end{array}$ & $\begin{array}{l}2480 \\
32.8 \pm 9.1 \\
2.4 \pm 0.7 \\
42.2 \pm 11.6 \\
1582(63.7) \\
1480(59.6)\end{array}$ \\
\hline \multicolumn{7}{|l|}{ GOLD disease severity, n (\%) } \\
\hline $\begin{array}{l}\geq 80 \% \text { (GOLD I) } \\
50 \% \text { to }<80 \% \text { (GOLD 2) } \\
30 \% \text { to }<50 \% \text { (GOLD } 3 \text { ) } \\
<30 \% \text { (GOLD } 4 \text { ) } \\
\text { Missing }\end{array}$ & $\begin{array}{l}0(0.0) \\
3(0.6) \\
300(62.6) \\
176(36.7) \\
0(0.0)\end{array}$ & $\begin{array}{l}\text { I }(0.2) \\
\text { I }(0.2) \\
311(63.3) \\
176(35.8) \\
2(0.4)\end{array}$ & $\begin{array}{l}I(0.1) \\
4(0.4) \\
611(63.0) \\
352(36.3) \\
2(0.2)\end{array}$ & $\begin{array}{l}1(0.1) \\
6(0.5) \\
760(61.1) \\
473(38.1) \\
3(0.2)\end{array}$ & $\begin{array}{l}2(0.2) \\
3(0.2) \\
761(61.3) \\
474(38.2) \\
2(0.2)\end{array}$ & $\begin{array}{l}3(0.1) \\
9(0.4) \\
1521(61.2) \\
947(38.1) \\
5(0.2)\end{array}$ \\
\hline \multicolumn{7}{|l|}{ Blood eosinophil count, n (\%) } \\
\hline $\begin{array}{l}<300 \text { cells } / \mu \mathrm{L} \\
\geq 300 \text { cells } / \mu \mathrm{L} \\
\text { Missing }\end{array}$ & $\begin{array}{l}383(80.0) \\
78(16.3) \\
18(3.8)\end{array}$ & $\begin{array}{l}399(81.3) \\
76(15.5) \\
16(3.3)\end{array}$ & $\begin{array}{l}782(80.6) \\
154(15.9) \\
34(3.5)\end{array}$ & $\begin{array}{l}959(77.2) \\
252(20.3) \\
32(2.6)\end{array}$ & $\begin{array}{l}971(78.2) \\
238(19.2) \\
33(2.7)\end{array}$ & $\begin{array}{l}1930(77.7) \\
490(19.7) \\
65(2.6)\end{array}$ \\
\hline
\end{tabular}

(Continued) 
Table I (Continued).

\begin{tabular}{|c|c|c|c|c|c|c|}
\hline & \multicolumn{3}{|c|}{ Triple Therapy at Screening } & \multicolumn{3}{|c|}{ Overall Trial Population } \\
\hline & $\begin{array}{l}\text { ICS } \\
\text { Continuation, } \\
n=479\end{array}$ & $\begin{array}{l}\text { ICS } \\
\text { Withdrawal, } \\
n=49 \text { I }\end{array}$ & Total, $n=970$ & $\begin{array}{l}\text { ICS } \\
\text { Continuation, } \\
n=\mid 243\end{array}$ & $\begin{array}{l}\text { ICS } \\
\text { Withdrawal, } \\
n=1242\end{array}$ & Total, $n=2485$ \\
\hline \multicolumn{7}{|l|}{ Exacerbation history } \\
\hline Patients with exacerbations, $n$ & 479 & 490 & 969 & 1243 & $124 \mid$ & 2484 \\
\hline $\begin{array}{l}\text { Moderate-to-severe exacerbations in } \\
\text { the previous year, mean } \pm S D\end{array}$ & $1.9 \pm 1.4$ & $1.7 \pm 1.2$ & $1.8 \pm 1.3$ & $1.7 \pm 1.3$ & $1.7 \pm 1.3$ & $1.7 \pm 1.3$ \\
\hline $\begin{array}{l}\text { Severe exacerbations in the previous } \\
\text { year, mean } \pm S D\end{array}$ & $0.5 \pm 1.0$ & $0.3 \pm 0.7$ & $0.4 \pm 0.8$ & $0.4 \pm 0.8$ & $0.4 \pm 0.7$ & $0.4 \pm 0.8$ \\
\hline
\end{tabular}

Note: ${ }^{a}$ Before the run-in period where all patients took triple therapy.

Abbreviations: COPD, chronic obstructive pulmonary disease; FEV , forced expiratory volume in I second; FVC, forced vital capacity; GOLD, Global Initiative for Chronic Obstructive Lung Disease; ICS, inhaled corticosteroids; SD, standard deviation.

Table 2 Time to First COPD Exacerbation and Number of COPD Exacerbations (in Patients Taking Triple Therapy at Screening and in the Overall Trial Population)

\begin{tabular}{|c|c|c|c|c|}
\hline & \multicolumn{2}{|c|}{ Triple Therapy at Screening } & \multicolumn{2}{|c|}{ Overall Trial Population } \\
\hline & $\begin{array}{l}\text { ICS Continuation, } \\
\mathrm{n}=479\end{array}$ & $\begin{array}{l}\text { ICS Withdrawal, } \\
n=49 \text { I }\end{array}$ & $\begin{array}{l}\text { ICS Continuation, } \\
n=I 243\end{array}$ & $\begin{array}{l}\text { ICS Withdrawal, } \\
n=1242\end{array}$ \\
\hline \multicolumn{5}{|c|}{ Time to first moderate or severe on-treatment COPD exacerbation } \\
\hline Patients with exacerbations, $\mathrm{n}(\%)$ & $259(54.1)$ & $280(57.0)$ & $550(44.2)$ & $580(46.7)$ \\
\hline $\begin{array}{l}\text { Hazard ratio, ICS withdrawal versus ICS } \\
\text { continuation }(95 \% \mathrm{Cl})^{\mathrm{b}}\end{array}$ & \multicolumn{2}{|l|}{$1.05(0.89,1.25)$} & \multicolumn{2}{|l|}{$1.06(0.94,1.19)$} \\
\hline \multicolumn{5}{|c|}{ Number of moderate or severe on-treatment COPD exacerbations } \\
\hline Events, $n^{c}$ & 495 & 494 & 953 & 972 \\
\hline $\begin{array}{l}\text { Mean number of events per patient-year } \\
(95 \% \mathrm{Cl})^{d}\end{array}$ & $1.29(1.14,1.45)$ & $1.31(1.16,1.48)$ & $0.91(0.83,0.99)$ & $0.95(0.87,1.04)$ \\
\hline $\begin{array}{l}\text { Rate ratio, ICS withdrawal versus ICS } \\
\text { continuation }(95 \% \mathrm{Cl})^{\text {d }}\end{array}$ & \multicolumn{2}{|l|}{$1.02(0.86,1.20)$} & \multicolumn{2}{|l|}{$1.05(0.93,1.18)$} \\
\hline \multicolumn{5}{|c|}{ Time to first severe on-treatment COPD exacerbation } \\
\hline Patients with exacerbations, $\mathrm{n}(\%)$ & $85(17.7)$ & $98(20.0)$ & $167(13.4)$ & $189(15.2)$ \\
\hline $\begin{array}{l}\text { Hazard ratio, ICS withdrawal versus ICS } \\
\text { continuation }(95 \% \mathrm{Cl})^{\mathrm{b}}\end{array}$ & \multicolumn{2}{|l|}{$1.23(0.92,1.64)$} & \multicolumn{2}{|l|}{$1.20(0.98,1.48)$} \\
\hline \multicolumn{5}{|c|}{ Number of severe on-treatment COPD exacerbations } \\
\hline Events, $n^{c}$ & 107 & 118 & 205 & 230 \\
\hline $\begin{array}{l}\text { Mean number of events per patient-year } \\
(95 \% \mathrm{Cl})^{d}\end{array}$ & $0.28(0.22,0.35)$ & $0.31(0.25,0.39)$ & $0.20(0.17,0.23)$ & $0.23(0.19,0.27)$ \\
\hline 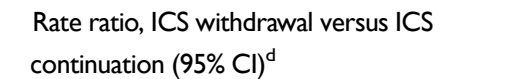 & \multicolumn{2}{|l|}{$1.12(0.82,1.53)$} & \multicolumn{2}{|l|}{ I.I5 (0.92, I.45) } \\
\hline
\end{tabular}

Notes: ${ }^{a}$ Before the run-in period where all patients took triple therapy; ${ }^{\text {b }}$ Hazard ratio from Cox proportional hazards model with terms for baseline FEV ${ }_{1}$; ${ }^{\mathrm{T}}$ otal number of events with onset between the day of the first randomized dose and the day after the last randomized dose, both inclusive; ${ }^{d} \mathrm{Negative}$ binomial regression adjusted for time at risk.

Abbreviations: $\mathrm{Cl}$, confidence interval; COPD, chronic obstructive pulmonary disease; $\mathrm{FEV}$, forced expiratory volume in I second; ICS, inhaled corticosteroids. 


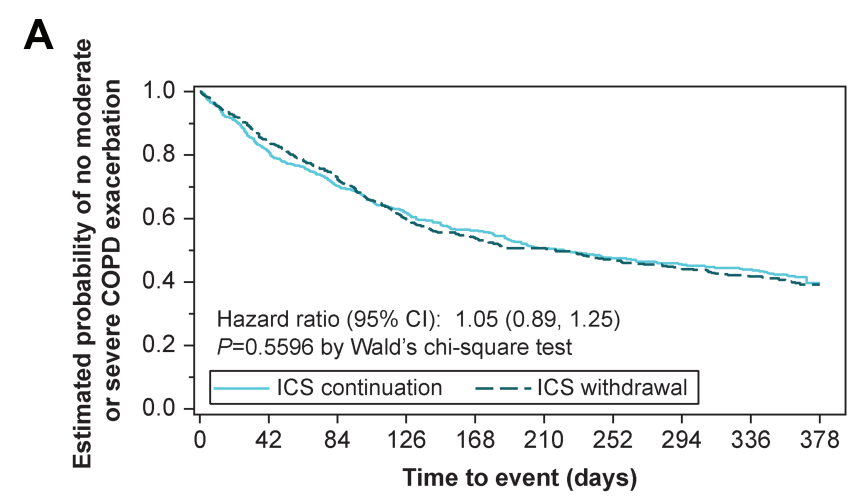

Numbers at risk

$\begin{array}{llllllllll}\text { ICS continuation } 479 & 378 & 312 & 263 & 236 & 206 & 191 & 179 & 172 & 3\end{array}$

$\begin{array}{llllllllll}\text { ICS withdrawal } 491 & 405 & 339 & 273 & 238 & 220 & 202 & 186 & 170 & 8\end{array}$
B

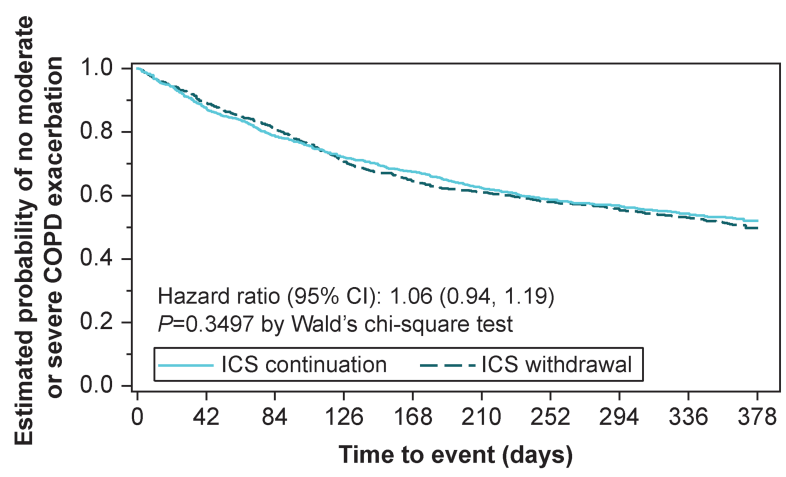

Numbers at risk

$\begin{array}{llllllllll}\text { ICS continuation } 1243 & 1059 & 927 & 827 & 763 & 694 & 646 & 615 & 581 & 14\end{array}$ $\begin{array}{llllllllll}\text { ICS withdrawal } 1242 & 1090 & 965 & 825 & 740 & 688 & 646 & 607 & 570 & 19\end{array}$

Figure 2 Kaplan-Meier estimates of the probability of no moderate or severe on-treatment COPD exacerbation in (A) patients taking triple therapy at screening and (B) overall trial population.

Abbreviations: $\mathrm{Cl}$, confidence interval; COPD, chronic obstructive pulmonary disease; ICS, inhaled corticosteroids.

A

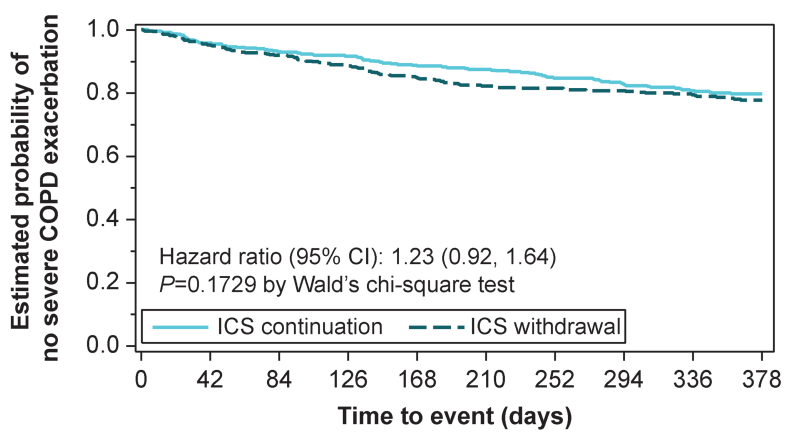

Numbers at risk ICS continuation $479 \quad 445 \quad 410 \quad 381 \quad 361 \quad 347 \quad 332 \quad 317 \quad 304 \quad 6$ $\begin{array}{llllllllll}\text { ICS withdrawal } 491 & 458 & 423 & 386 & 351 & 331 & 324 & 312 & 297 & 9\end{array}$
B

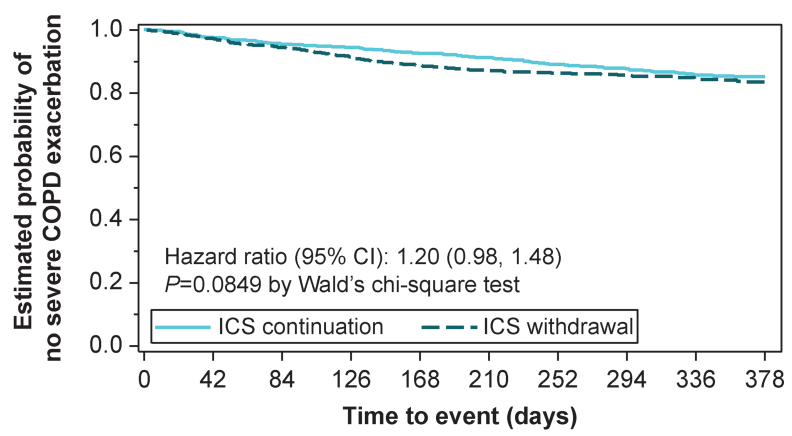

Numbers at risk

ICS continuation $1243 \quad 1180 \quad 1117 \quad 1066 \quad 1026 \quad 993 \quad 957 \quad 928 \quad 895 \quad 20$ $\begin{array}{llllllllll}\text { ICS withdrawal } 1242 & 1189 & 1119 & 1044 & 986 & 941 & 918 & 889 & 863 & 25\end{array}$

Figure 3 Kaplan-Meier estimates of the probability of no severe on-treatment COPD exacerbation in (A) patients taking triple therapy at screening and (B) overall trial population.

Abbreviations: $\mathrm{Cl}$, confidence interval; COPD, chronic obstructive pulmonary disease; ICS, inhaled corticosteroids.

Pulmonary Medicine, Enschede (COPE) study, ICS withdrawal was associated with rapid recurrent exacerbations. ${ }^{13}$ The proportion of patients who developed $\geq 1$ exacerbation was higher in the placebo group (57\%) than in the ICS group (47.2\%). Moreover, patients who discontinued ICS after 4 months of ICS treatment (placebo group) experienced rapid recurrent exacerbations compared with those who continued ICS (21.5\% versus $4.9 \%$, respectively). Health-related quality of life (QoL) also significantly deteriorated in patients who discontinued ICS. ${ }^{13}$ Similarly, in the COPD and Seretide: a Multi-Center Intervention and Characterization (COSMIC) study, the rate of mild exacerbations significantly increased, lung function significantly decreased, and dyspnea worsened a year after ICS withdrawal in patients originally treated with LABA+ICS (salmeterol+fluticasone). ${ }^{14}$ Finally, in a 5-year observational follow-up of the Groningen and Leiden Universities Corticosteroids in Obstructive Lung Disease (GLUCOLD) study, ICS withdrawal in patients with moderate-to-severe COPD was associated with worsened airway hyperresponsiveness and QoL and deterioration of lung function. ${ }^{15}$

In light of the conflicting results, a meta-analysis of 4 randomized controlled trials, including the COPE and COSMIC studies, was performed. ${ }^{16}$ No significant difference was observed between the ICS withdrawal and ICS continuation groups. Although the ICS withdrawal group had a 1.11-fold higher risk of exacerbations, the definition of exacerbation was not consistent across 3 of the 4 trials; therefore, the results should be interpreted with caution. ${ }^{16}$ In another meta-analysis of 10 randomized controlled 


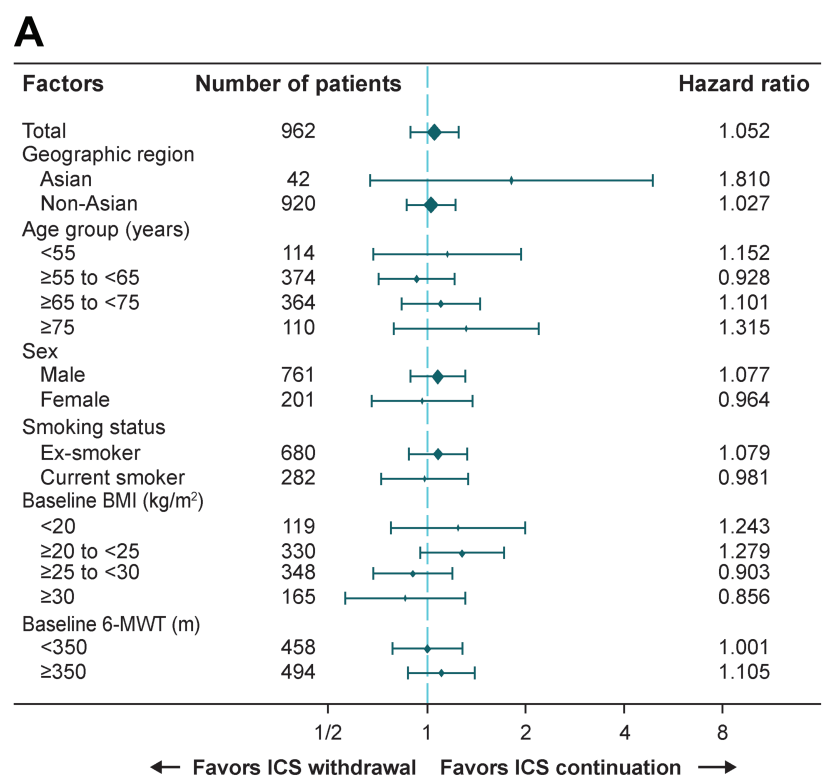

B

\begin{tabular}{|c|c|c|}
\hline Factors & Number of patients & Hazard ratio \\
\hline Total & 2441 & 1.058 \\
\hline \multicolumn{3}{|l|}{ Geographic region } \\
\hline Asian & $\longmapsto+$ & 1.127 \\
\hline Non-Asian & $\mapsto-1$ & 1.051 \\
\hline \multicolumn{3}{|l|}{ Age group (years) } \\
\hline$<55$ & $\longmapsto||$, & 1.041 \\
\hline$\geq 55$ to $<65$ & $\longmapsto-1$ & 0.951 \\
\hline$\geq 65$ to $<75$ & $\longmapsto$ & 1.192 \\
\hline$\geq 75$ & ]$_{1}$ & 1.061 \\
\hline \multicolumn{3}{|l|}{ Sex } \\
\hline Male & $\mapsto \bullet$ & 1.075 \\
\hline Female & 431 & 1.015 \\
\hline \multicolumn{3}{|l|}{ Smoking status } \\
\hline Ex-smoker & $\mapsto \bullet-1$ & 1.095 \\
\hline \multirow{2}{*}{\multicolumn{3}{|c|}{ Baseline BMI $\left(\mathrm{kg} / \mathrm{m}^{2}\right)$}} \\
\hline & & \\
\hline$<20$ & $\longmapsto$ & 0.942 \\
\hline $\begin{array}{l}\geq 20 \text { to }<25 \\
\geq 25 \text { to }<30\end{array}$ & 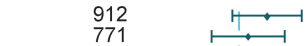 & $\begin{array}{l}1.174 \\
1.054\end{array}$ \\
\hline$\geq 30$ & $\longmapsto$ & 0.964 \\
\hline \multicolumn{3}{|l|}{ Baseline 6-MWT $(\mathrm{m})$} \\
\hline$<350$ & $\longmapsto$ & 1.035 \\
\hline \multirow[t]{2}{*}{$\geq 350$} & $\longmapsto$ & 1.092 \\
\hline & $1 / 2$ & \\
\hline
\end{tabular}

Figure 4 Forest plot of time to first moderate or severe COPD exacerbation in (A) patients taking triple therapy at screening and (B) overall trial population. Abbreviations: 6-MWT, 6-minute walk test; BMI, body mass index; COPD, chronic obstructive pulmonary disease; ICS, inhaled corticosteroids.

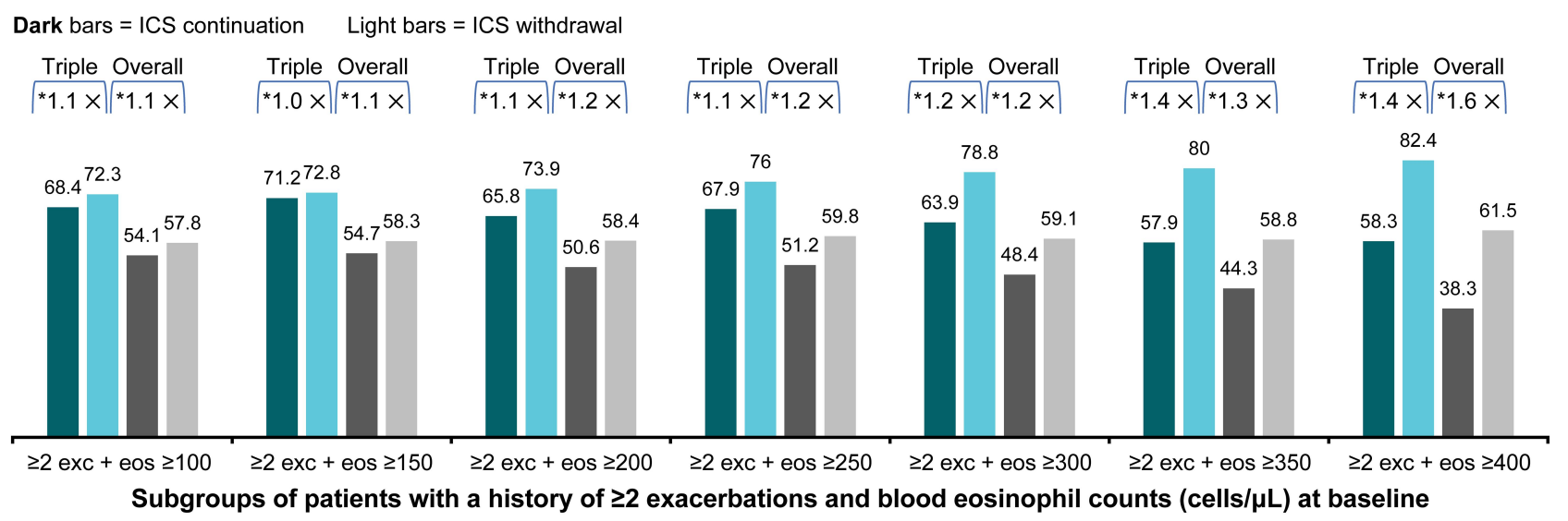

Figure 5 Percentage of patients with at least one moderate or severe COPD exacerbation (in patients taking triple therapy at screening ${ }^{\mathrm{a}}$ and in the overall trial population). Notes: ${ }^{a}$ Before the run-in period where all patients took triple therapy; The numbers above the bars indicate percentages of patients with at least one exacerbation during the study; *Indicates the ratio of the percentages of patients with at least one exacerbation within the ICS continuation and ICS withdrawal groups.

Abbreviations: COPD, chronic obstructive pulmonary disease; $\mathrm{FEV}_{1}$, forced expiratory volume in I second; eos, blood eosinophil counts; exc, exacerbations; ICS, inhaled corticosteroids.

trials and real-world studies, ICS withdrawal did not significantly increase the rate of exacerbations; however, a significant decrease in lung function and impaired QoL was observed. ${ }^{17}$ Collectively, these results imply that, although ICS withdrawal may not negatively impact all patients, understanding which patients are likely to benefit from ICS and, therefore, which patients should continue taking triple therapy is important.

The results of the present analyses confirmed that frequent exacerbators ( $\geq 2$ exacerbations in the previous year) with high blood eosinophil counts could benefit from continuing ICS treatment, as the risk of exacerbation increased nominally with increasing blood eosinophil levels. However, there was high variability due to small sample sizes in this subgroup analysis. Our results are consistent with those of previous post hoc analyses of the WISDOM trial which showed that the rate of moderate or severe exacerbations increased after ICS withdrawal in patients with blood eosinophil counts of $\geq 2 \%$ (of the total white blood cell count) or $\geq 300$ cells $/ \mu \mathrm{L}$, suggesting that these patients benefited from ICS-based therapy. ${ }^{18,19}$ In the SUNSET study, only patients with blood eosinophil counts 
$\geq 300$ cells $/ \mu \mathrm{L}$ had an increased risk of exacerbations and greater decline in lung function compared with patients with counts $<300$ cells $/ \mu \mathrm{L}^{10}{ }^{10}$

Based on cumulative results from ICS withdrawal studies, use of peripheral blood eosinophil counts as a biomarker to guide ICS-based therapy is recommended in GOLD for reducing COPD exacerbations. ${ }^{1}$ Clinicians should consider the long-term risks as well as benefits associated with ICS before prescribing an ICS. ${ }^{20}$ As mentioned, escalation to triple therapy is recommended if patients experience exacerbations despite optimal LAMA+LABA therapy and have blood eosinophil counts of $\geq 100$ cells $/ \mu \mathrm{L}$. ${ }^{1}$ Furthermore, patients with blood eosinophil counts of $\geq 300$ cells $/ \mu \mathrm{L}$ have a greater likelihood of experiencing exacerbations following ICS withdrawal; therefore, they should be monitored closely if de-escalation is attempted. Overall, findings from the present analyses suggest that physicians choosing to prescribe triple therapy are doing so, in part, because of the increased exacerbation risk. Additionally, even though many patients would be categorized as GOLD B, clinicians may be better at identifying an appropriate therapy for patients with COPD.

A limitation of these subgroup analyses was that the number of patients with frequent exacerbations and high eosinophil counts was low. Therefore, these analyses were exploratory in nature, and the results need to be confirmed in subsequent robust studies.

\section{Conclusion}

The risk of first moderate or severe COPD exacerbation was increased in patients taking triple therapy at screening versus the overall WISDOM trial population. Furthermore, ICS withdrawal did not increase the risk of exacerbations in patients taking triple therapy at screening compared with the overall trial population. Patients with a history of frequent exacerbations ( $\geq 2$ exacerbations in the previous year) and higher blood eosinophil counts could benefit from ICS-based therapy. The findings suggest that stepwise ICS withdrawal could be considered in particular in patients with lower blood eosinophil counts and without a history of frequent exacerbations.

\section{Abbreviations}

BMI, body mass index; CI, confidence interval; COPD, chronic obstructive pulmonary disease; GOLD, Global Initiative for Chronic Obstructive Lung Disease; HR, hazard ratio; $\mathrm{FEV}_{1}$, forced expiratory volume in 1 second; ICS, inhaled corticosteroids; LABA, long-acting $\beta_{2^{-}}$ agonist; LAMA, long-acting muscarinic antagonist; QoL, quality of life; RR, rate ratio; SD, standard deviation.

\section{Data Sharing Statement}

Results of the WISDOM trial and subgroup analysis of patients with blood eosinophil count of $\geq 300$ cells $/ \mu \mathrm{L}$ and history of $\geq 2$ exacerbations have been published previously: https://www.ncbi.nlm.nih.gov/pubmed/25196117 and https://www.ncbi.nlm.nih.gov/pubmed/27066739. Individual patient data are not publicly accessible but are available on request via the transparency platform https:// clinicalstudydatarequest.com/Study-Sponsors.aspx.

\section{Ethics Approval and Informed Consent}

The study was carried out in accordance with the Declaration of Helsinki, local regulations, and the ICH Harmonised Tripartite Guideline for Good Clinical Practice. Local institutional review boards, independent ethics committees, and competent authorities approved the protocol. All patients provided written, informed consent.

\section{Acknowledgments}

The authors meet the criteria for authorship as recommended by the International Committee of Medical Journal Editors. The authors received no direct compensation related to the development of the manuscript. Writing, editorial support, and formatting assistance was provided by Suchita Nath-Sain, PhD, Vidula Bhole, MD, MHSc, and Maribeth Bogush, PhD, of Cactus Life Sciences (part of Cactus Communications), which was contracted and compensated by Boehringer Ingelheim Pharmaceuticals, Inc. (BIPI) for these services. BIPI was given the opportunity to review the manuscript for medical and scientific accuracy as well as intellectual property considerations.

\section{Author Contributions}

All authors made substantial contributions to conception and design, acquisition of data, or analysis and interpretation of data; took part in drafting the article or revising it critically for important intellectual content; gave final approval of the version to be published; and agree to be accountable for all aspects of the work.

\section{Funding}

Boehringer Ingelheim Pharmaceuticals, Inc. 


\section{Disclosure}

GTF reports grants, personal fees, and nonfinancial support from Boehringer Ingelheim and AstraZeneca; grants and personal fees from Novartis, Pearl Therapeutics, Sanofi, Sunovion, and Theravance; grants from Altavant and Forest; and personal fees from Circassia, Meda, Verona, Mylan, Innoviva, and GlaxoSmithKline, outside the submitted work. AS, KT, and AM are employees of Boehringer Ingelheim. HM reports personal fees from Boehringer Ingelheim during the conduct of the study and personal fees from AstraZeneca, Novartis, and ndd Medical Technologies, Inc. outside the submitted work. HW reports personal fees from Boehringer Ingelheim during the conduct of the study and personal fees from Berlin-Chemie, Chiesi, GlaxoSmithKline, AstraZeneca, Menarini, Novartis, Takeda, and Roche, outside the submitted work. The authors report no other conflicts of interest in this work.

\section{References}

1. GOLD. Global initiative for chronic obstructive lung disease. 2020. Available from: https://goldcopd.org/wp-content/uploads/2019/11/ GOLD-2020-REPORT-ver1.0wms.pdf. Accessed November 13, 2019.

2. Global Initiative for Asthma (GINA). Global strategy for asthma management and prevention. 2019. Available from: https://ginasthma. org/wp-content/uploads/2019/06/GINA-2019-main-report-June-2019wms.pdf. Accessed November 13, 2019.

3. Barnes PJ. Immunology of asthma and chronic obstructive pulmonary disease. Nat Rev Immunol. 2008;8(3):183-192. doi:10.1038/nri2254

4. Barnes PJ. Inhaled corticosteroids in COPD: a controversy. Respiration. 2010;80(2):89-95. doi:10.1159/000315416

5. Price D, Yawn B, Brusselle G, Rossi A. Risk-to-benefit ratio of inhaled corticosteroids in patients with COPD. Prim Care Respir J. 2013;22 (1):92-100. doi:10.4104/pcrj.2012.00092

6. Chalmers JD, Tebboth A, Gayle A, Ternouth A, Ramscar N. Determinants of initial inhaled corticosteroid use in patients with GOLD A/B COPD: a retrospective study of UK general practice. NPJ Prim Care Respir Med. 2017;27(1):43. doi:10.1038/s41533-017-0040-Z

7. Fitch K, Iwasaki K, Pyenson B, Plauschinat C, Zhang J. Variation in adherence with global initiative for chronic obstructive lung disease (GOLD) drug therapy guidelines: a retrospective actuarial claims data analysis. Curr Med Res Opin. 2011;27(7):1425-1429. doi:10.1185/ 03007995.2011.583230

8. Brusselle G, Price D, Gruffydd-Jones K, et al. The inevitable drift to triple therapy in COPD: an analysis of prescribing pathways in the UK. Int $J$ Chron Obstruct Pulmon Dis. 2015;10:2207-2217. doi:10.2147/COPD.S91694
9. Magnussen H, Disse B, Rodriguez-Roisin R, et al. Withdrawal of inhaled glucocorticoids and exacerbations of COPD. $N$ Engl J Med. 2014;371(14):1285-1294. doi:10.1056/NEJMoa1407154

10. Chapman KR, Hurst JR, Frent SM, et al. Long-term triple therapy deescalation to indacaterol/glycopyrronium in patients with chronic obstructive pulmonary disease (SUNSET): a randomized, doubleblind, triple-dummy clinical trial. Am J Respir Crit Care Med. 2018;198(3):329-339. doi:10.1164/rccm.201803-0405OC

11. Magnussen H, Watz H, Kirsten A, et al. Stepwise withdrawal of inhaled corticosteroids in COPD patients receiving dual bronchodilation: WISDOM study design and rationale. Respir Med. 2014;108 (4):593-599. doi:10.1016/j.rmed.2014.01.002

12. Vogelmeier C, Worth H, Buhl R, et al. "Real-life" inhaled corticosteroid withdrawal in COPD: a subgroup analysis of DACCORD. Int $J$ Chron Obstruct Pulmon Dis. 2017;12:487-494. doi:10.2147/COPD. S125616

13. van der Valk P, Monninkhof E, van der Palen J, Zielhuis G, van Herwaarden C. Effect of discontinuation of inhaled corticosteroids in patients with chronic obstructive pulmonary disease: the COPE study. Am J Respir Crit Care Med. 2002;166(10):1358-1363. doi:10.1164/ rccm.200206-512OC

14. Wouters EF, Postma DS, Fokkens B, et al. Withdrawal of fluticasone propionate from combined salmeterol/fluticasone treatment in patients with COPD causes immediate and sustained disease deterioration: a randomised controlled trial. Thorax. 2005;60(6):480-487. doi:10.1136/thx.2004.034280

15. Kunz LIZ, Postma DS, Klooster K, et al. Relapse in $\mathrm{FEV}_{1}$ decline after steroid withdrawal in COPD. Chest. 2015;148(2):389-396. doi:10.1378/chest.14-3091

16. Nadeem NJ, Taylor SJ, Eldridge SM. Withdrawal of inhaled corticosteroids in individuals with COPD - a systematic review and comment on trial methodology. Respir Res. 2011;12:107. doi:10.1186/1465-9921-12-107

17. Calzetta L, Matera MG, Braido F, et al. Withdrawal of inhaled corticosteroids in COPD: a meta-analysis. Pulm Pharmacol Ther. 2017;45:148-158. doi:10.1016/j.pupt.2017.06.002

18. Watz H, Tetzlaff K, Wouters EF, et al. Blood eosinophil count and exacerbations in severe chronic obstructive pulmonary disease after withdrawal of inhaled corticosteroids: a post-hoc analysis of the WISDOM trial. Lancet Respir Med. 2016;4(5):390-398. doi:10.1016/S2213-2600(16)00100-4

19. Calverley PMA, Tetzlaff K, Vogelmeier C, et al. Eosinophilia, frequent exacerbations, and steroid response in chronic obstructive pulmonary disease. Am J Respir Crit Care Med. 2017;196(9):12191221. doi:10.1164/rccm.201612-2525LE

20. Singh S, Loke YK. An overview of the benefits and drawbacks of inhaled corticosteroids in chronic obstructive pulmonary disease. Int J Chron Obstruct Pulmon Dis. 2010;5:189-195. doi:10.2147/COPD. $\mathrm{S} 6942$

\section{Publish your work in this journal}

The International Journal of COPD is an international, peer-reviewed journal of therapeutics and pharmacology focusing on concise rapid reporting of clinical studies and reviews in COPD. Special focus is given to the pathophysiological processes underlying the disease, intervention programs, patient focused education, and self management protocols. This journal is indexed on PubMed Central, MedLine and CAS. The manuscript management system is completely online and includes a very quick and fair peer-review system, which is all easy to use. Visit http://www.dovepress.com/testimonials.php to read real quotes from published authors. 